\title{
MALAYSIA-CHINA BILATERAL RELATIONS, 1974-2018
}

\author{
Md Nasrudin Md Akhir, \\ Lee Chee Leong and Hafiz Muhammad Tahir Ashraf
}

This paper analyzes the bilateral ties of Kuala Lumpur-Beijing over four decades in the political, economic and socio-cultural fields. Firstly, the paper discusses the historical background of Malaysia-China informal relations from the Kingdom of Malacca; the British era; the early stages of Malaysia's independence; as well as the Cold War era. Secondly, the paper examines the beginnings of Kuala Lumpur-Beijing diplomatic relations from 1974 until the demise of the Malayan Communist Party in 1989. Thirdly, this is followed by an examination of bilateral developments between 1990 and 2008. The section analyzes the extent to which the principle of openness in Malaysian foreign policies was followed, cooperation within the framework of regionalism as well as how the rise of China's economic power has had positive impact on bilateral relations. More significantly, the paper then extends the discussion to Malaysia-China relations under Mohd Najib Abdul Razak which began in 2008 and ended with the advent of the new government of Pakatan Harapan in Malaysia in May 2018. Presently, Malaysia's foreign policy towards China is facing a revamp under Dr. Mahathir Mohamad's leadership. Yet the paper argues that the current government's action enhances comprehensive cooperation, particularly in the political and economic spheres.

Keywords: Malaysia-China relations, regionalism, Communism, Mohd Najib Abdul Razak, Mahathir Mohamad, Pakatan Harapan

\section{Historical Background of Informal Malaysia-China Relations}

The earliest record of Malaysia's historical relations with China was found in Han Shu written by Ban $\mathrm{Gu}$, stated that there were maritime ties between China and India since the first century. The majority of Chinese scholars have acknowledged that this maritime relationship did indeed mark the early history of Malaysia-China trading relations. Archaeological findings of ceramic materials of the Qin and Han dynasties in the Johor River Valley further proves the existence of trade between Malacca and China in the first century. ${ }^{1}$ When Malacca emerged as an important kingdom in the Malay Archipelago, China's political relations with the state began in the third century after the Wu dynasty sent Kang Tai and Zhu Ying as peaceful emissaries to Malaya. Meanwhile, during the Song Dynasty, Nambei and Liang, emissaries from the Malay kingdom, were sent to meet Chinese officials who presented gifts and fragrances. Malaya's political relations with China continued into the Sui, Tang, Song and Yuan Dynasties in 1368.

\footnotetext{
${ }^{1}$ Kong Yuanzhi, Cheng Ho Muslim Tionghoa: Misteri Perjalanan Muhibah di Nusantara, Jakarta: Yayasan Pustaka Obor Indonesia, 2011, p. 128. Professor Kong Yuanzhi was a visiting professor at the Department of East Asian Studies, University of Malaya in the late 1990s.
} 
Even though the Malay world's relations with China has been predicated to have begun since $131 \mathrm{AD},{ }^{2}$ however, a significant relationship started only during the Ming dynasty when Malacca received a visit from Admiral Yi Qing, an emissary from the Chinese Emperor in 1403. A few years later, the burgeoning trade relationship between both kingdoms generated the Chinese kingdom's interest in Malacca, which culminated in the sending over of Admiral Cheng Ho in 1410. Officially, Malacca at that time was already acknowledged as a kingdom by the Ming dynasty. ${ }^{3}$ This relationship was further strengthened when Parameswara (Megat Iskandar Shah) who was the Sultan of Malacca, visited Emperor Yung Lo in $1411^{4}$ and at the end of that visit, the Chinese kingdom conferred an official seal and a yellow umbrella as recognition of the Malaccan Malay Sultanate. With the existence of such cordial relations and protection given by the Chinese kingdom, Malacca was free from the threat of Majapahit and Siam and this situation opened up space for Malacca to develop rapidly as a famed center of trade and dissemination of knowledge. ${ }^{5}$

However, the competition to control natural resources led to the invasion by Western imperialist powers of Southeast Asia in general and Malaysia in particular. ${ }^{6}$ The Portuguese invasion of Malacca in 1511, followed by the Dutch colonialism of Malacca in 1641 destroyed Malacca's role as the main trading port of Southeast Asia. The arrival of the British in Malaya in 1786 saw the exploitation of the tin mining industry which later attracted Chinese migrants participating in mining activities. This huge influx of migrants from China to Southeast Asia and Malaysia happened twice, first wave in the $17^{\text {th }}$ century, followed by the second in the $19^{\text {th }}$ century. ${ }^{7}$

\section{Malaysia-China Relations Prior to 1974}

The rise of communism in Asia after World War Two presented challenges for Asian countries that had just achieved independence. Malaysia's situation was very critical as it was facing a communist threat together with the emergence of the democracy-communism bloc ideological confrontation. The intervention of the United States in containing the rise of communism in Asia through the Southeast Asia Treaty Organization (SEATO) in 1954 and the Containment theory helped to control peace and stability in Malaysia and the possibility of threat from foreign powers. Malaysia's proximity to North Vietnam and Indochina which was communist-based made Kuala Lumpur put its trust in Britain and the Commonwealth countries through the Anglo-Malayan Defence Agreement (AMDA) followed by the Five Power Defence Agreements (FPDA) in defending the country's security.

While the global situation was shadowed by the complexity of the ideological confrontation, Malaysia faced the challenge of developing its economy. Malaysia experienced the Japanese Occupation from 1941-1945 together with the communist threat

\footnotetext{
${ }^{2}$ Lukman Thaib, "Kedinamikan Hubungan ASEAN-China: Rujukan Khas ke atas Malaysia," in Obaidellah Mohamad, China: Isu dan Hubungan Luar, Kuala Lumpur: Institute of Chinese Studies, University of Malaya, 2004, p. 215. Refer also K.G. Tregonning (ed.), Malaysian Historical Sources, Singapore: University of Singapore, 1962.

${ }^{3}$ Kong Yuanzhi, Cheng Ho Muslim Tionghoa: Misteri Perjalanan Muhibah di Nusantara, Jakarta: Yayasan Pustaka Obor Indonesia, 2011, pp. 130-132.

${ }^{4}$ http://www.umno-online.my/?p=62832

${ }^{5}$ http://eprints.usm.my/15538/1/Sejarah_Panjang_Hubungan_Malaysia_-_China.pdf

${ }^{6}$ Charles Hirschman, "The Making of Race in Colonial Malaya: Political Economy and Racial Ideology," Sociology Forum, Vol. 1, Issue 2, Spring 1986, p. 333.

${ }^{7}$ Zhuang Guotu and Wang Wangbo, "Migration and Trade: The Role of Overseas Chinese in Economic Relations between China and Southeast Asia," International Journal of China Studies, Vol. 1, No. 1, January 2010, p. 175.
} 
since 1930 while under British rule. Therefore, having ties with its allies was one of the mechanisms to overcome internal and external security at that time. The Malaysian model aimed to contain communism while developing its economic sector. Poverty and backwardness were identified as the main factors that motivated the poorer classes to become attracted to the communist ideology which fought for equal rights. Hence, economic development became a panacea to open up free trade and democracy to fight against communist ideals. It must be noted that before independence itself, Malaysia had implemented plans to contain communism under British rule. After achieving independence, the government introduced several land development plans such as the Federal Land Development Authority (FELDA) in order get rid of communist ideology and influence. Malaysia was also fortunate because it had rich natural resources such as rubber and tin which were in wide demand in the international market at that time. The FELDA scheme was put to good use to cultivate rubber.

The formulation of Malaysia's foreign policy was mostly suited to the situation and paradigm of its relationship with Britain together with Western capitalist countries due to Malaysia's position as a former British colony. ${ }^{8}$ After achieving independence on 31 August 1957, Malaysia began forging diplomatic ties with neighboring countries in Southeast Asia as well as among the Commonwealth countries such as Australia, England, India, Pakistan, Sri Lanka and other non-Commonwealth countries like the United States and Japan. It cannot be denied that Malaysia's participation in the Commonwealth brought benefits with the adoption of the administrative system, diplomacy, education, trade, the economic system and defence.

During the counter claims on Sabah and Sarawak by neighbouring countries in the mid1960s, Malaysia had to face various challenges due to its pro-West and anti-communist policies. Nonetheless, on 16 September 1963, the Federation of Malaysia was formed consisting of Peninsula Malaysia, Sabah, Sarawak and Singapore. This formation created tension and Philippines' claim on Sabah and Sarawak became more intense. Indonesia, which had protested greatly against the formation of the Federation of Malaysia, saw itself as a major power and lobbied the Third World countries in Asia and Africa to isolate Malaysia diplomatically. Pressure by the Philippines and Indonesia through the United Nations (UN) made it difficult for Kuala Lumpur to obtain support from its neighbours to form the Federation of Malaysia. During the Second Summit of the Non-Aligned Movement (NAM) which was held in Cairo in 1964, Malaysia's nomination to become a member was rejected, which further aggravated the crisis in Malaysia. In that situation, Tunku Abdul Rahman decided that a change in Malaysia's foreign policy had to take place. The choice included Malaysia's participation in NAM as well as maintaining the non-alignment policy and the neutrality doctrine. At the same time, he activated Malaysia's role through the Organization of Islamic Cooperation (OIC). Meanwhile, Malaysian diplomacy was strengthened with its participation in the Association of Southeast Asian Nations (ASEAN) beginning 8 August 1967.

The United States' pivot to Asia also influenced Malaysia's foreign policy. After an initiative was started since July 1971, President Nixon had made a trip to China and met with Mao Zedong on 21 February 1972, which became a focal change towards the alignment of power under the Cold War confrontation. Malaysia therefore realigned its foreign policy orientation based on the change in the United States' foreign policy. ${ }^{9}$ Malaysia obtained

\footnotetext{
${ }^{8}$ Md. Nasrudin Md. Akhir, "Five Decades of Malaysia-Japan Relations," in Md. Nasrudin Md. Akhir \& Rohayati Paidi (eds.), Japan and the Asia-Pacific, Kuala Lumpur: Department of East Asian Studies, 2009, pp. 53-54.

${ }^{9}$ Griffin, Nicholas, Ping Pong Diplomacy: The Secret History Behind the Game That Changed the World, New York: Simon \& Schuster, 2014. On 17 September 1968, the United States' Department of State sent a letter to
} 
cooperation from the United States to solve its ongoing conflict with Indonesia regarding the issue of Sabah and Sarawak. With that, Malaysia then a new foreign policy orientation after discovering the United States had signed a normalization agreement with China. However, Malaysia's domestic situation did not allow it to initiate diplomatic relations immediately with China. Many perceived that there would not be any benefits for Malaysia in cooperating with the Chinese at that point in time but the option for bilateral normalization remained for the future. Therefore, to justify a diplomatic agreement with China, firstly Malaysia developed diplomatic relations with North Korea in June 1973. According to Ahmad Kamil Jaafar, Malaysia endeavoured to build relationships with communist countries based on the neutrality doctrine. Therefore, Malaysia established diplomatic relations with East Germany, Mongolia and North Vietnam from 1972 to $1973 .^{10}$

In May 1971, Tengku Razaleigh Hamzah headed the Perbadanan Nasional (PERNAS) unofficial visit to China and three months later, this was followed by a reciprocal trip by a Chinese trade mission to Kuala Lumpur which led to the export of 40,000 tonnes of Malaysian rubber for the Chinese market. ${ }^{11}$ The total bilateral trade for Malaysia-China in 1971 only recorded US\$27.8 million. ${ }^{12}$ In October 1971, Chou Enlai invited a Malaysian team to participate in the Asia-Latin America ping pong tournament in Beijing. The head of the Malaysia delegation was Michael Chen Wing Sum, the Alliance Secretary General and Chairman of the Olympic Committee of Malaysia (OCM). ${ }^{13}$ Abdul Razak prepared a letter and asked Michael Chen to seek the Chinese government's view in possibly establishing diplomatic relations with Malaysia. ${ }^{14}$ Even though efforts towards official relations with China had begun in 1971, however a diplomatic agreement was not able to be realized due to the dual citizenship issue and the status of roughly 300,00 ethnic Chinese in Malaysia. ${ }^{15}$

Once, the Shanghai Declaration was signed by Malaysia and China, which did not acknowledge dual citizenship, only then did Malaysia and China signed a diplomatic agreement on 31 May 1974. China then announced that:

the Chinese government suggesting a discussion at ambassadorial level which was well received by the Chinese government. In the summer of 1970, Henry Kissinger ordered Vernon Walters, the United States ambassador in France to convey the American government's intent to the Chinese ambassador in France to hold secret talks which eventually brought about normalization efforts in relations with China.

${ }^{10}$ Ahmad Kamil Jaafar, Growing Up with the Nation, Kuala Lumpur: Marshall Cavendish, 2013, p. 44-46.

${ }^{11}$ Xia Ming, "Sino-Malaysian Trade Ties and Its Prospects,” Economic Quarterly, April 1990, p. 21.

${ }^{12}$ Shee Poon Kim, "The Political Economy of Mahathir's China Policy: Economic Cooperation, Political and Strategic Ambivalence," Ritsumeikan Annual Review of International Studies, Vol. 3, 2004, p. 60.

${ }^{13}$ Walter Isaacson, Kissinger, New York: Simon \& Schuster, 1992, p. 339. Ping-pong diplomacy made history when in April 1971, a world ping pong tournament was held in Nagoya, Japan and by accident Glenn Cowan, an American ping pong player who had missed the bus that was supposed to transport American ping pong players, boarded the Chinese team's bus for sight-seeing instead. Zhang Zedong, a Chinese player, started a conversation and there was exchange of gifts which eventually led to praise from Mao and Nixon until it brought about the normalization of Sino-American relations.

${ }^{14}$ Bernama, 31 May 2013. Keynote speech by Tan Sri Dato' Michael Chen Wing Sum at the Photo Exhibition Celebrating the $40^{\text {th }}$ Anniversary of the Establishment of Malaysia-China Diplomatic Relations at University of Malaya on 21 April 2014. Michael Chen was also the Secretary General of the Ping Pong Afro-Asia-America Alliance at that time.

${ }^{15}$ Keynote Speech of Tan Sri Dato' Michael Chen Wing Sum at the Photo Exhibition Celebrating the $40^{\text {th }}$ Anniversary of the Establishment of Malaysia-China Diplomatic Relations at University of Malaya on 21 April 2014. 


\begin{abstract}
Anyone who originated from China and already has Malaysian citizenship will on their own lose the status of Chinese citizenship. For those who still have Chinese citizenship, they are under Malaysian law and have to respect Malaysian customs and traditions and their rights as well as importance will be protected by the Chinese government and respected by the Chinese government. ${ }^{16}$
\end{abstract}

\title{
Malaysia-China Relations, 1974-1989
}

Abdul Razak's pragmatic foreign policy led to the establishment of Malaysia-China diplomatic relations on 31 May 1974. Looking back at the early history of Abdul Razak's trip to Beijing from 28 May to 2 June 1974, his efforts to establish diplomatic relations with China also opened up important channels in the establishment of other ASEAN countries' diplomatic relations with China. The Philippines and Thailand, for instance, established diplomatic relations with Beijing in July 1975, Singapore and Indonesia in 1990 and Brunei Darussalam in 1991.

Abdul Razak's historic meeting with Mao Zedong, the Chinese President together with Zhou Enlai, the Chinese Prime Minister in Beijing at the end of May 1974 cemented a strategic historic Kuala Lumpur-Beijing relationship which exist till today. The sincerity of both leaders during the discussion process culminated in an official announcement on 31 May 1974. ${ }^{17}$ With this bilateral agreement, it marked the end of an episode in Malaysian foreign policy that was coloured by anti-communist orientation, anti-China and favouring the West. The normalization produced a Malaysian foreign policy that was based on the 'equal distance strategy' towards outside powers. Conversely, it also highlighted China's necessary move to establish diplomatic relations with non-communist countries in Southeast Asia which has been further strengthened now.

Nevertheless, Kuala Lumpur-Beijing relations met with some problems in 1975 when the Chinese government sent a telegram congratulating the Malayan Communist Party (MCP) for its $45^{\text {th }}$ anniversary in Malaysia. ${ }^{18}$ Hussein Onn as the third Prime Minister took a more cautious stance of Kuala Lumpur-Beijing relations. Malaysia-China relations from 1975-1977 became rather weak due to this problem and other developments in Southeast Asia involving disputes between China-Vietnam and Vietnam-Cambodia that were heating up due to Beijing's close relations with Russia. However, efforts to restore Malaysia-China relations became a priority for the Malaysian leadership when visits from high officials from both governments were arranged with more consistency. For example, Hussein Onn reciprocated a 1978 visit by Deng Xiaoping, the Deputy Prime Minister of China to Malaysia. ${ }^{19}$

After Dr. Mahathir Mohamad was elected as the fourth Prime Minister in 1981, Malaysia-China bilateral relations became closer when he initiated more progressive relations between both countries. During Dr Mahathir's visit to China in 1985, an Agreement for the

\footnotetext{
${ }^{16}$ Lukman Thaib, "Kedinamikan Hubungan ASEAN-China: Rujukan Khas ke atas Malaysia," in Obaidellah Mohamad (ed.), China: Isu dan Hubungan Luar, Kuala Lumpur: Institute of Chinese Studies, University of Malaya, 2004, p. 220.

${ }^{17}$ http://malay.cri.cn/781/2009/05/30/181s99084.htm

${ }^{18}$ Keynote Speech by Tan Sri Dato' Michael Chen Wing Sum at the Photo Exhibition Celebrating the $40^{\text {th }}$ Anniversary of the Establishment of Malaysia-China Diplomatic Relations at University of Malaya on 21 April 2014.

${ }^{19}$ China Daily. http://www.chinadaily.com.cn/china/2009malaysia/2009-06/01/content_7959800.htm. Accessed on 23 June 2018.
} 
Avoidance of Double Taxation and the Prevention of Fiscal Evasion with Respect to Taxes on Income was signed which prompted a new era in bilateral economic ties for Kuala Lumpur-Beijing. Dr. Mahathir's official visit took him from Beijing to Shanghai, Suzhou, Xian, and finally Guangzhou. He led a roughly 200-strong delegation including cabinet ministers, government officials, and private sector businessmen and entrepreneurs ${ }^{20}$ Following that, under Dr. Mahathir's administration, other agreements were signed including, Agreement on Maritime Transport in 1987; Trade Agreement in 1988; Agreement concerning the Reciprocal and Encouragement and Protection of Investments in 1988 and Agreement Relating to Civil Air Transport in 1989.

In January 1988, Malaysia abolished administrative regulations that were imposed on obtaining permission to import goods from China. The total administrative cost of $5 \%$ was also abolished in the same year. The Malaysian government also got rid of restrictions on businessmen and traders. Prior to that trips were only allowed to the Canton Trade Fair. ${ }^{21}$ In the effort to ease trade, the Malaysian immigration introduced multiple exit permits to enable Malaysian businessmen to stay longer in China. ${ }^{22}$

After the break up of the Soviet Union and the fall of the Berlin Wall in 1989, the MCP threat became weaker until it led to the 1989 Haadyai Treaty between the Malaysian and Thai governments as well as the MCP. Consequently, the end of the MCP threat brought about a new era in Malaysia-China relations in several fields based on mutual interests.

\section{Malaysia-China Relations 1990-2008}

Malaysia-China relations after the end of the Cold War was more focused on the economic sector following Dr Mahathir's pragmatic foreign policy. This was despite the ongoing conflicting claims on Spratly Islands by both Kuala Lumpur and Beijing, which led to some fluctuation in relations. But, the frequency of bilateral visits and trade missions enabled trade and investment treaties to be signed which in turn encouraged continuous and active trade. $\mathrm{Dr}$ Mahathir's efforts to encourage Malaysia-China economic cooperation during 1990-2003 were continued with the strengthening of Kuala Lumpur-Beijing's diplomatic relations through the frequent visits of officials of the highest level. In December 1990, Li Peng, the Chinese Prime Minister visited Malaysia and from 6-12 September 1991, Sultan Azlan Muhibuddin Shah, the Yang DiPertuan Agong made a trip to China. This was followed by a visit from Yang Shangkun, the Chinese President in January 1992 while Dr. Mahathir had his second official visit to China from 13-22 June 1993. In November 1994, Jiang Zemin, the Chinese President made an official trip to Malaysia and Dr. Mahathir made his third trip to China in August 1996. While in Beijing, Dr. Mahathir witnessed the signing of 15 business agreements between Malaysia and China regarding cooperation involving highway toll building projects, car and spare parts manufacturing, construction of factories and power energy. ${ }^{23}$

The closeness of Kuala Lumpur-Beijing relations continued when Tuanku Ja'afar Tuanku Abdul Rahman, the Yang DiPertuan Agong visited China from 8-15 July 1997 while Li Peng made his second trip to Malaysia in August 1997. Dr. Mahathir had his third official trip in 1999 which was followed by Sultan Salahuddin Abdul Aziz Shah Alhaj, the Yang DiPertuan Agong, who made a trip to China in April 2001. Hu Jintao, the Vice President of

\footnotetext{
${ }^{20}$ Ahmad Kamil Jaafar, Growing Up with the Nation, Singapore: Marshall Cavendish Editions, 2013, p. 89.

21 “China Visits Under Study Says Khir," The Star, 13 January 1972; "China Visits Rules Will be Reviewed Dewan Told," The Star, 5 February 1970.

22 “Tun Razak Gives 'OK' to China Visit,” The Star, 28 September 1972.

${ }^{23}$ Bernama News, 27 August 1996.
} 
China visited Malaysia in April 2002 and when Abdullah Ahmad Badawi took over the reins from Dr. Mahathir, his first official trip abroad was to China which was held on 31 May 2004. ${ }^{24}$ In December 2005, Wen Jiabao, the Chinese Prime Minister made a trip to Malaysia while Abdullah visited Naning in conjunction with the Commemorative Summit marking the $15^{\text {th }}$ Anniversary of ASEAN-China Dialogue Relations in October 2006. The visit of Tuanku Mirzan Zainal Abidin, the Yang DiPertuan Agong to Beijing to attend the opening ceremony of the Beijing Olympics was held in August 2008 and this was followed by a visit from Abdullah in October 2008 to attend the $7^{\text {th }}$ Asia-Europe Summit in China. ${ }^{25}$ Based on the frequency of visits by the political leaders of both countries throughout 1990-2008, it is evident that people-to-people interaction did not only occur at the lower levels but also occurred at the highest governmental level for Malaysia and China. This situation was vastly different when compared to before 1990 when there were limited interactions due to less frequency high level visits from the top officials of both countries.

One of the initiatives to encourage further economic development by Dr. Mahathir was to involve the private sector in Malaysia's economic development. Within this context, to explore new business opportunities, the sending of trade missions, participation in international trade expos and the involvement of Malaysian trade delegates that accompanied DR. Mahathir during his official visits overseas increased. For example, Dr. Mahathir once brought along more than 200 trade delegates to China aimed at introducing Malaysian investors to the Chinese investors. After the Malaysia-China Friendship Association and the China-Malaysia Friendship Association were formed, more efforts were held to promote trade cooperation. ${ }^{26}$ With the electrical and electronic (E\&E) sector actively being developed since the early 1980s and the establishment of the Multimedia Super Corridor (MSC) focusing on information and communication technology (ICT), China's involvement in Malaysia became more visible.

In 1990, the total trade of Malaysia-China recorded US $\$ 1.18$ billion which increased to US\$1.33 billion in 1991 and US\$1.48 billion in 1992. This number continued to increase to a total of US\$7.6 billion in 2001 and US\$14.3 billion in 2002 until it enabled Malaysia to emerge as China's biggest trading partner among the ASEAN countries, taking over Singapore's spot for the first time. ${ }^{27}$ Table 1 shows the total trade for Malaysia-China from 1992 to 2008 which demonstrated an encouraging growth rate even though it sided China more with a trade surplus.

The table below shows that Dr. Mahathir's first visit to China in 1995 which was followed by official visits in 1993, 1994, 1996 and 1999 yielded results and improved economic relations between Beijing and Kuala Lumpur. ${ }^{28}$ Among the important bilateral agreements that were sealed during his time included: Agreement of Cooperation in Science and Technology in 1992; Agreement of Cooperation in the Field of Information and Sports Agreement in 1993; as well as Memorandum of Understanding in the Field of Education in 1997. Many analysts agree that Dr. Mahathir was pivotal in driving Malaysia-China trade relations to a very significant level. In fact, Abdullah Ahmad Badawi equally contributed in

\footnotetext{
${ }^{24}$ Abdullah's grandfather came to Malaysia from the South China territory and he married a Malay woman and settled in Penang.

25 Perkara Penting dalam Sejarah Hubungan RRC-Malaysia. March, 2010. http://malay.cri.cn/901/2010/03/30/123s110068.htm

${ }^{26}$ Datuk Majid Ahmad Khan's speech at University of Malaya on 21 April 2014.

${ }^{27}$ Shee Poon Kim, "The Political Economy of Mahathir's China Policy: Economic Cooperation, Political and Strategic Ambivalence," Ritsumeikan Annual Review of International Studies, Vol. 3, 2004, p. 61.

${ }^{28} \mathrm{http} / / /$ malay.cri.cn/901/2010/03/30/123s110068.htm,
} 
strengthening Kuala Lumpur-Beijing relations through his first visit to China on 28 May 2004 which completed the officiating of a new Malaysian embassy in Beijing.

Table 1: Malaysia-China Trade, 1992-2008

\begin{tabular}{|c|c|c|c|}
\hline Year & $\begin{array}{c}\text { Total Export } \\
\text { (RM Billion) }\end{array}$ & $\begin{array}{c}\text { Total Import } \\
\text { (RM Billion) }\end{array}$ & Trade Balance \\
\hline 1992 & 1.96 & 2.48 & -0.52 \\
\hline 1993 & 3.09 & 2.82 & 0.27 \\
\hline 1994 & 1.49 & 5.06 & 3.58 \\
\hline 1995 & 4.9 & 4.3 & 0.61 \\
\hline 1996 & 4.8 & 4.72 & 0.08 \\
\hline 1997 & 5.26 & 6.27 & -1.02 \\
\hline 1998 & 7.77 & 7.26 & 0.51 \\
\hline 1999 & 8.8 & 8.15 & 0.65 \\
\hline 2000 & 11.51 & 12.32 & -0.81 \\
\hline 2001 & 14.68 & 14.47 & 0.21 \\
\hline 2002 & 19.97 & 23.47 & -3.51 \\
\hline 2003 & 25.87 & 27.73 & -1.86 \\
\hline 2004 & 32.14 & 39.27 & -7.13 \\
\hline 2005 & 35.22 & 49.88 & -14.65 \\
\hline 2006 & 42.6 & 58.2 & -15.6 \\
\hline 2007 & 53 & 64.7 & -11.7 \\
\hline 2008 & 63.4 & 58.2 & 5.2 \\
\hline
\end{tabular}

Source: Adapted from http://www.matrade.gov.my/ms/pembeli-luar negara/keupayaan-industri/statistik-perdagangan-malaysia/38,

http://www.statistics.gov.my/portal/index.php?lang=bm,

http://www.bnm.gov.my/files/publication/ar/bm/2004/cp01.pdf

Regional developments too had a role in strengthening bilateral relations. For example, on 2 July 1997, the Asian financial crisis occurred which caused the value of the Asian currencies to fall drastically. ${ }^{29}$ Dr. Mahathir decided to tether the exchange rate of the ringgit to the rate of RM3.80 to US $\$ 1$. This was supported by China despite opposition from Western capitalist countries. China also supported Malaysia's suggestion to form the Asian Monetary Fund (AMF) and Malaysia also supported China's entry into the World Trade Organization (WTO) which eventually enabled China to assimilate with the free market economic system. All these developments allowed Malaysia-China trade relations to grow tremendously after the 1997 Asian financial crisis. ASEAN member countries also changed their perception of the 'Chinese threat theory' and willingly integrated China into the region with the formation of ASEAN+1 and ASEAN+3 aimed at benefitting of regional economies. The ASEAN-China Free Trade Area (ACFTA) Agreement in 2003 also led to an increase in Malaysia-China trade whereby China emerged as Malaysia's fourth important trade partner up to 2008.

\footnotetext{
${ }^{29}$ Md. Nasrudin bin Md. Akhir, "Jepun dan Krisis Kewangan Asia Tenggara," (Japan and the Southeast Asian Financial Crisis) Pemikir, July-September 2000, pp. 81-102.
} 


\section{Malaysia-China Relations under Najib Abdul Razak, 2008-2018}

Bilateral Malaysia-China trade relations continued to expand under the leadership of Najib Abdul Razak. For Najib, the relations had a special meaning. This can be related to his father, Abdul Razak's whose significant contribution initiated Malaysia-China diplomatic relations in 1974. Not surprisingly, similar to Abdullah Badawi, Najib's first official visit abroad after he was elected as Prime Minister was to China.

\section{Political and Security Cooperation}

Najib like Dr. Mahathir continues the frequency of personal visits to China as well as the visits of the higher officials. Najib's visits to China included the celebration of MalaysiaChina's $35^{\text {th }}$ diplomatic relations; participation in Business Forum in 2009; Round Table Discussion on Malaysia-China Business in 2009, Opening Ceremony of Zhongyou BSS (Qinhuangdao) Petropipe Co. Ltd.; China-ASEAN $8^{\text {th }}$ Expo in 2011, China-ASEAN $10^{\text {th }}$ Expo in 2013, Malaysia-China $40^{\text {th }}$ Anniversary of diplomatic relations in 2014 as well as subsequent official visits from 2015 to $2017^{30}$ before the fall of the Alliance government on 9 May 2018. The strengthening of Malaysia-China diplomatic relations under Najib's administration led to economic relations realized through the massive involvement of Chinese firms in mega projects in Malaysia. Unfortunately, the economic development agenda involving Chinese firms in Malaysia was linked to several improper awarding of contracts which at the end became disadvantageous to Malaysia.

From the security aspect, the potential for cooperation between Malaysia and China in combating maritime conflict issues in the South China Sea saw some improvements in bilateral discussions. As proposed by Najib in his speech while officiating the 27th ISIS Asia-Pacific Roundtable in Kuala Lumpur, countries that had claims in the South China Sea should ensure this issue is settled by individual countries concerned. In this aspect, Malaysia's priority was to ensure the issue was free from outside interferences. ${ }^{31}$ If both parties involved become successful in creating an effective mechanism to settle the overlapping claims, its was deemed if such a model could then be replicated by China and other ASEAN countries. Therefore, Malaysian leadership perceived it had the moral integrity and legitimacy to play an important role in the Spratly Islands claim disputes.

Najib next proposed that all parties involved discussed the possibility of signing a Code of Conduct ${ }^{32}$ and until now talks between ASEAN and China are ongoing, however progress is rather limited. Najib further recommended that both parties cooperate in exploiting the natural resources of the South China Sea by referencing to the Malaysia Thailand joint development project at Thailand $\mathrm{Bay}^{33}$ as an important step towards the settlement of territorial dispute issues. This proposal is consistent with Malaysia's policy

\footnotetext{
30 "PM Najib arrives in China for official visit," New Straits Times, 31 October 2016; Bernama News, 2 April 2017; "Najib in Beijing for 6-day official visit to China," Malaysian Reserve, 2 April 2017.

${ }^{31}$ Daniel Ten Kate, Bloomberg, 4 June 2013, http://www.bloomberg.com/news/2013-06-04/malaysia-pushesjoint-development-to-solve-asia-sea-disputes.html.

${ }^{32}$ Malaysian Prime Minister's speech, Dato Sri Mohd. Najib bin Hj. Tun Razak, "The Opening Session of the National Colloquium on Malaysia's Chairmanship of ASEAN 2015," Malaysian Prime Minister's Department, 8 April 2014, http://www.pmo.gov.my/?menu=speech\&page=1676\&news_id=700\&speech_cat=2 .

33 "Malaysian PM Echoes Beijing's Call for Joint Development in South China Sea," South China Morning Post, 5 June 2013, www.scmp.com/new s/asia/article/1253564/malaysian-pm-echoes-beijings-call-jointdevelopment-south-china-sea.
} 
since 2009 where Najib already stated his willingness to discuss with China bilaterally regarding the South China Sea issue. ${ }^{34}$

Li Keqiang, the Chinese Prime Minister also proposed the idea of maritime partnership relations between ASEAN and China. ${ }^{35}$ To achieve this, he informed China's intention to help ASEAN countries in implementing cooperative maritime programs and projects through the China-ASEAN Maritime Cooperation Fund. ${ }^{36}$ However, talks have not shown any signs of it being realized. Moreover, up to November 2018, there has been no improvements in Malaysia and China's handling of sensitive maritime issues in the South China Sea.

The formation of a secretariat between the Malaysian Alliance Youth (Barisan Nasional/BN) wing with the Communist Youth League (CYL) of the Communist Party of China in $2010^{37}$ showed that Malaysia and China not only cooperated at the government level, but also at party level. The party level cooperation was initiated by the then Minister of Defence and Acting Minister of Transport - Hishammuddin Hussein. Hishamudding was also the head of the BN Youth from March 2004 to March 2009 till Khairy Jamaluddin, the Youth and Sports Minister replaced him. The continuity of cooperation of both parties not only enriched bilateral cooperation, but became a unique bilateral relationship which is rarely found in other ASEAN countries.

\section{Economic Cooperation}

Under Najib's administration, economic cooperation was the main pillar in bilateral relations. Due to this pragmatic measure, Malaysia and China's trade growth recorded an increase of $58.4 \%$ from 2009 to 2013 with total trade recorded from RM128.3 billion to RM203.2 billion during that period. From 2008 to 2011, Malaysia recorded a trade surplus of RM40.93 billion, however from 2012 to February 2014, Malaysia recorded a trade deficit with China of RM13.07 billion. The total of Malaysia's trade surplus on China showed an increasing trend which grew from RM5.2 billion in 2008 to RM6.2 billion in 2009 before recording a drastic increase of RM13.7 billion in 2010 and RM15.8 billion in 2011.

Nonetheless, Malaysia experienced a trade deficit with China beginning 2012 and the total of trade deficit also grew from RM3.1 billion in 2012 to RM9.3 billion in 2013. For the period of 2014 to 2017, the Malaysia-China trade deficit also recorded a larger deficit and was clearly biased towards China as shown in Table 2. The biggest total trade deficit was recorded in 2016 with RM43.8 billion. This change was partly linked to the effect of the new economic development policy introduced by the Hu-Wen administration in 2012. In early 2012, Prime Minister Wen Jiabao predicted a lower Gross Domestic Product (GDP) growth of about $7.5 \%$, the first time China had adjusted its GDP growth rate after maintaining at $8 \%$ growth for seven years. ${ }^{38}$ This decrease in the GDP growth rate subsequently led to a decrease in the demand in the domestic construction sector, which stabilized trade. Table 2 shows that for a continuous period of six years from 2012 to 2017, Malaysia faced a trade deficit with China in it overall total.

\footnotetext{
${ }^{34}$ Kazuyuki Katayama, China's Rise and Japan's Malaysia Policy, KL: UM Press, 2013, p. 47.

35 "Premier Li Outlined Five Proposals for the Strengthening of ASEAN-China Ties (Translation from Chinese)," Xinhuanet, 3 September 2013, http://news.xinhuanet.com/world/2013-09/03/c_117214202.htm.

36 "China to Promote Maritime Connectivity with ASEAN, Says Vice FM," Xinhua, 5 August 2012, http://www.gov.cn/misc/2012-08/05/content_2198775.htm.

37 "Secretariat to be formed between Barisan and China's youth wings, The Star, 12 October 2009, http://www.thestar.com.my/story.aspx/?file=\%2f2009\%2f10\%2f12\%2fnation $\% 2 \mathrm{f} 20091012160821 \&$ sec $=$ nation 38 "China's 2012 GDP growth rate at 7.5\%," Xinhua, 5 March 2012, 
Table 2: Malaysia-China Trade, 2008-2017

\begin{tabular}{|l|l|l|l|}
\hline Year & $\begin{array}{l}\text { Total Export } \\
\text { (RM Billion) }\end{array}$ & $\begin{array}{l}\text { Total Import } \\
\text { (RM Billion) }\end{array}$ & $\begin{array}{l}\text { Trade } \\
\text { Balance }\end{array}$ \\
\hline 2008 & 63.4 & 58.2 & 5.2 \\
\hline 2009 & 67.2 & 61 & 6.2 \\
\hline 2010 & 80.1 & 66.4 & 13.7 \\
\hline 2011 & 91.5 & 75.7 & 15.8 \\
\hline 2012 & 88.7 & 91.8 & -3.1 \\
\hline 2013 & 96.9 & 106.2 & -9.3 \\
\hline 2014 & 92.3 & 115.5 & -23.2 \\
\hline 2015 & 101.5 & 129.4 & -27.9 \\
\hline 2016 & 98.6 & 142.4 & -43.8 \\
\hline 2017 & 126.2 & 164.5 & -38.3 \\
\hline
\end{tabular}

Source: Adapted from http://www.matrade.gov.my/ms/pembeli-luarnegara/keupayaan-industri/statistik-perdagangan-malaysia/38, http://www.statistics.gov.my/portal/index.php?lang=bm

China was Malaysia's main trading partner consuming $14.8 \%$ of Malaysia's total trade in 2013. This percentage was higher compared to Malaysia's traditional trading partners like Singapore (13.2\%), Japan (9.9\%), the United States (8\%), South Korea (4.2\%), Thailand (5.7\%) and Indonesia (4.5\%). Under Najib's administration, Malaysia expected China and ASEAN to sign a second free trade agreement (CAFTA 2.0) after negotiations were finalized $^{39}$ and hoped that China would continue to be the main trading partner for Malaysia in the long term. In addition, both countries' leaders agreed to improve bilateral trade relations through a five year plan (2013-2017) that was discussed during Chinese President Xi Jinping's visit to Kuala Lumpur in October $2013 .{ }^{40}$ However, concerns from various parties regarding the widespread involvement of Chinese firms in several mega projects in Malaysia (throughout 2013 till the first quarter of 2018) were raised as it was found that there were financial discrepancies in the awarding of contracts. Contracts were not given out through open tenders which meant the entire practice was open to corruption. In fact, Najib as the Prime Minister who was also the Minister of Finance Ministry was allegedly exposed to administrative wrongdoings and misuse of power in the awarding of contracts to Chinese firms. It was obvious that with the fall of Najib's administration in May 2018, this led to Dr. Mahathir's administration reviewing China's FDI in Malaysia and more damagingly delay the mega projects that had not begun yet. ${ }^{41}$ Chart 1 shows that Malaysia-China trade relations were still strong until August 2018 with a total of $13.73 \%$ from the overall total international trade and China was still the main trading partner for Malaysia.

\footnotetext{
39 "China to negotiate upgraded FTA with ASEAN," Xinhua, 26 October 2013, http://news.xinhuanet.com/english/china/2013-10/26/c_125601659.htm.

40 "Malaysia-China target US\$160 bln in bilateral trade by 2017," New Straits Times, 4 October 2013, http://www.nst.com.my/mobile/latest/malaysia-china-target-us-160-bln-in-bilateral-trade-by-2017-1.368942

${ }^{41}$ Dr. Mahathir Mohammad has announced about this deferment right after he was elected as the seventh Prime Minister.
} 


\section{Chart 1: Malaysia's Trade Composition by Partners, as of August 2018}

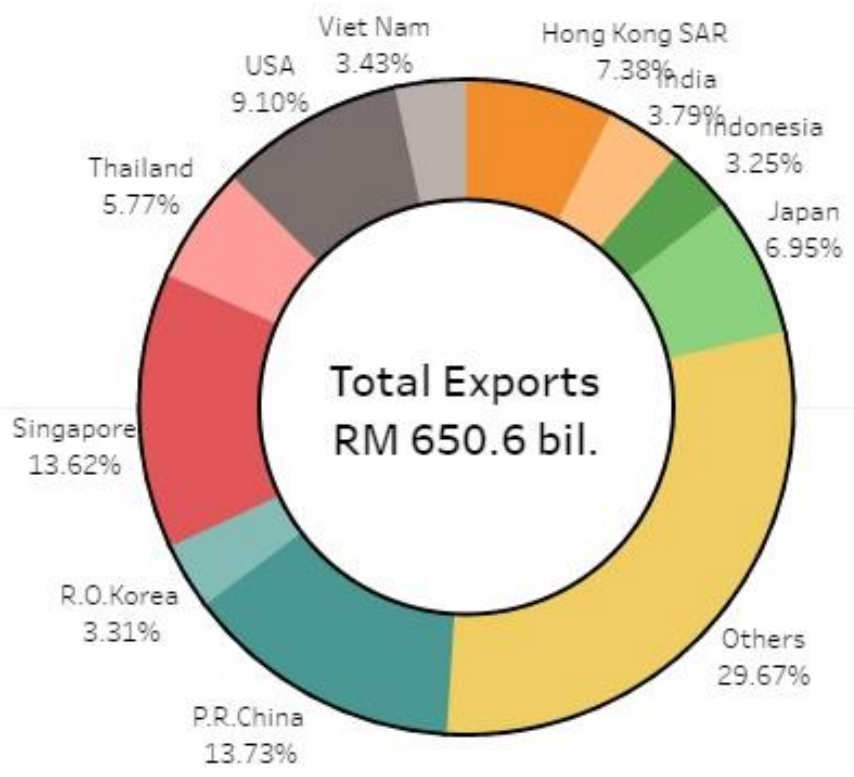

Source: Malaysian International Trade and Industry Ministry, 2018

China was also involved in importing palm oil. Malaysia's palm oil received positive demand since it was first introduced in the 1980s and this recorded a consistent demand until the mid2000s. In 2010, China was the main importer of Malaysia's crude palm oil with 11.37 million tonnes or $68.2 \%$ of Malaysia's total palm oil export. ${ }^{42}$ The total then increased to 7.34 million tonnes compared to 2009 when Malaysia exported 4.03 million tonnes of palm oil worth US\$2.81 billion (RM9.28 billion) to China.

Although the image of palm oil was once negatively affected due to claims that palm oil of having higher cholesterol content, however the revelation failed to impact on the continuous export to China. Partly this was because of the scientific discovery by Chinese scientists led by Professor Zhang Jian, who was also an ex-specialist at the Chinese Center for Disease Control and Prevention verified that palm oil had no affect on the health of humans. ${ }^{43}$ This scientific discovery was a testimony to the fact that Malaysia's palm oil industry is always committed to providing high quality oil based on its quality guarantee scheme to ensure the export of this product fulfilled international food safety standards. In 2012, China became the largest importer of Malaysian palm oil with a value of RM12.8 billion or 4.36 million tons. China was the largest export destination for palm oil and palm oil products from Malaysia which contributed $17.7 \%$ of the total global exports for Malaysia in $2012 .{ }^{44}$

According to the statistical report published by the Malaysian International Trade and Industry Ministry (MITI), for the period between January and October 2013, all palm oil exports to China totaled RM9.02 billion (3.9 million tons) compared to RM10.03 billion (3.3 million tons) for the same period in $2012 .{ }^{45}$ This total highlighted that even though the

\footnotetext{
42 http://www.usahawan.com/umum/industri-sawit-di-malaysia.html

${ }^{43} \mathrm{http} / /$ www.kppk.gov.my/index.php/ms/2012-10-31-06-45-41/mpic-in-the-news/news-year-2013/2067-

industri-sawit-douglas-optimistik-pelarasan-duti-eksport-tidak-jejas-eksport-msm-ke-china.html

${ }^{44} \mathrm{http}: / / w w w . k p p k . g o v . m y / i n d e x . p h p / m s / 2012-10-31-06-45-41 /$ mpic-in-the-news/news-year-2013/2067-

industri-sawit-douglas-optimistik-pelarasan-duti-eksport-tidak-jejas-eksport-msm-ke-china.html

45 There was an increase in the price of palm oil in the global market which impacted the total income.
} 
country's palm oil products were once criticized by the international community, this did not stop the export of this product to China based on the consistent demand until today. However, according to the statistics by the Malaysian Palm Oil Board, palm oil shipment into China has been declining since 2009's peak of four million tons. ${ }^{46}$ The shipment in 2016 was recorded at 1.88 million tons, the lowest in ten years since 2007. However, there is still room to grow Malaysia's palm oil export to China given the continuous increase in demand and consumption. According to Teresa Kok, the Primary Industries Minister, the additional 25 per cent import tax imposed by China on US soybean oil had resulted in reduced imports which created a reduction in the supply of edible oils while creating opportunities to increase Malaysian palm oil exports. In 2017, Malaysia exported 2.87 million tons of palm oil and palm oil derivatives worth RM9.42 billion to China. ${ }^{47}$

\section{Chinese Investments in Malaysia}

\section{Graph 1: China's FDI to Malaysia in the Manufacturing} Sector, 2008-2017

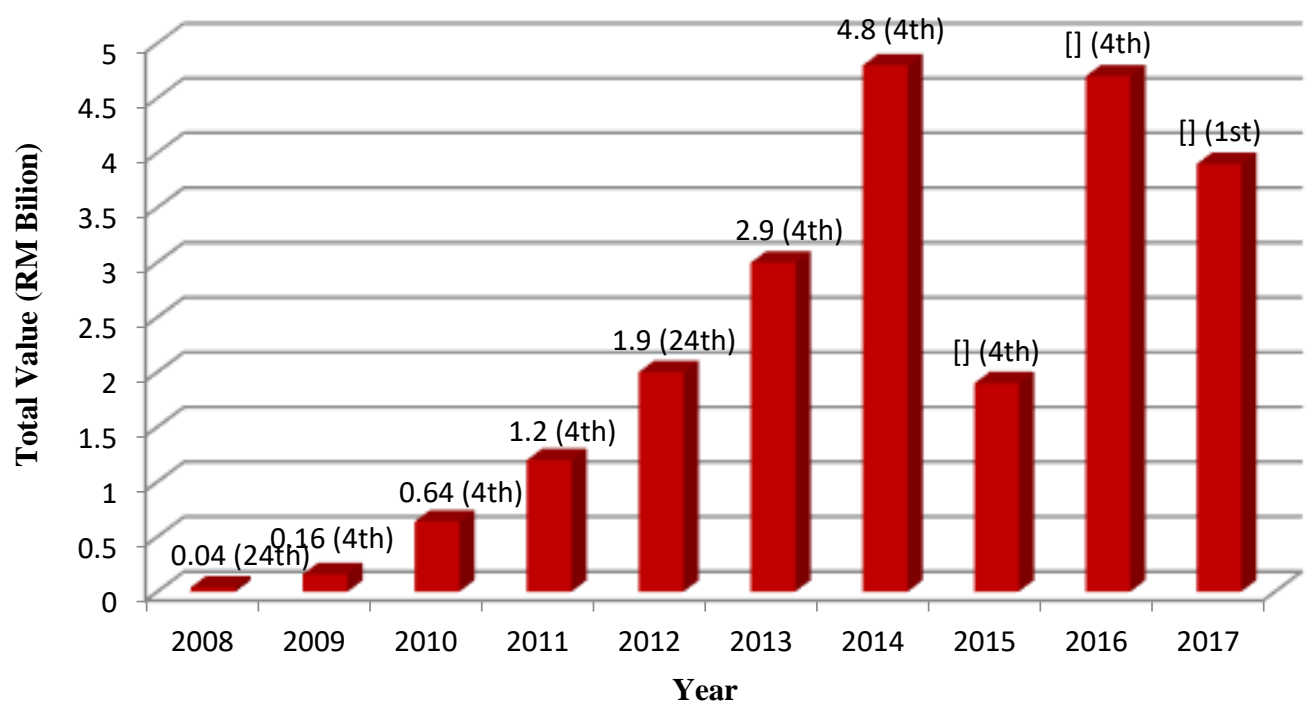

Source: Ministry of International Trade and Investments (MITI) and Malaysian Investment Development Authority (MIDA)

Overall, total Chinese FDI to Malaysia has been increasing steadily. From 2008 to 2013, China's total FDI to Malaysia increased from RM0.04 billion to RM3.02 billion, which recorded an increase of 75.5 times in that period. Together with this increase in the total FDI, China moved up from the 24th position in 2008 to fourth position in 2013 for investment in the manufacturing sector as shown in Graph 1. China's position at fourth place continued up to 2016 and in 2017, it jumped to become the main investor in the manufacturing sector. This has made China one of the main sources of FDI for Malaysia.

\footnotetext{
${ }^{46}$ China will import more palm oil products from Malaysia: Chinese Ambassador to Malaysia," New Straits Times, 2 February 2018.

47 "Room to grow palm oil exports to China - Kok," New Straits Times, 23 October 2018.
} 
Based on percentage, the total FDI from China was 9.5\% of the overall FDI total for the manufacturing sector (RM20.8 billion) in 2012. Traditional trading partners for Malaysia like Japan, Saudi Arabia and Singapore still maintained their first, second and third positions as FDI sources to Malaysia. There were many contributing factors for the increase in China's FDI to Malaysia. Firstly, Malaysia is a business-friendly country like Singapore. According to the latest World Bank's Doing Business Report 2014, Malaysia was at sixth place in a list of ten business-friendly countries that included Singapore, Hong Kong, New Zealand, the United States, and Denmark. This position was a big leap from $12^{\text {th }}$ place in 2012. With this reputation, Malaysia was expected to continue attracting the attention of foreign investors, especially from China. In this context, the implementation of entry point projects (EPP) under the Economic Transformation Program (ETP) and the agenda of the Iskandar Regional Development are expected to pioneer the further entry of Chinese investors. Even though the Pakatan Harapan government announced a review of all of China's less beneficial FDI to Malaysia, however there are no signs showing that China's FDI decreased in 2018.

Secondly, the Chinese government's policy also played an important role in the increase in FDI to Malaysia. The 'go global/go out' strategy that is one of China's foreign policy foundations has brought huge economic benefits to Malaysia. The Chinese government introduced this strategy by encouraging government-owned companies to invest abroad, especially in ASEAN countries. This strategy will be continued by the current administration of $\mathrm{Xi}-\mathrm{Li}$, and China also intends to reduce the requirements that restrict free movement of capital from its local companies. ${ }^{48}$ It can be argued these policies contributed heavily to the increase of China's FDI to Malaysia.

China's total investment in Malaysia's manufacturing sector in 2012 and 2013 respectively recorded RM1.98 billion and RM3.02 billion. The total Chinese investment in the same period showed an increase at the rate of $84.4 \%$ and China invested in a total of 22 projects in 2012. Japan, which traditionally is Malaysia's trading partner and investor was the country with the highest investment in 2012 with a FDI total of RM2.80 billion, and RM3.02 billion in 2013. An encouraging development was when the United States' total investment as well as the EU's to Malaysia increased respectively to RM6.32 billion and RM5.12 billion in 2012 and 2013. An interesting development was also noted when South Korea and Singapore also increased their investment respectively from RM1.64 billion and RM2.22 billion in 2012 to RM5.48 billion and RM4.52 billion respectively in 2013. This increase in total investment is equal to a growth of $234 \%$ for South Korea and $104 \%$ for Singapore.

For the period of five years from 2013 to 2017, the Malaysian government had predicted RM16.2 billion (US\$5 billion) a year for FDI from China. This was 5\% of China's outbound foreign direct investments (OFDI) which was estimated to be US\$500 billion from 2013 to $2017 .{ }^{49}$ In 2017, Malaysia became the fourth largest recipient of China's overseas direct investment globally, a surge from the 20th rank in 2015. In a short span of two years, FDI from China to Malaysia has skyrocketed from RM1.5 billion in the first quarter of 2015 to almost RM15 billion in the fourth quarter of 2017 according to the Department of Statistics Malaysia. ${ }^{50}$ Malaysia appeared to have emerged as one of the biggest venues in Southeast Asia in terms of bagging investments from China. Before May 2018, China committed to two major infrastructure projects in Malaysia, the East Coast Rail Link (ECRL) and the Malacca

48 "Li Keqiang: Yao jinyibu fangkuan zhongguo qiye "zouchuqu” de tiaojian (Li Keqiang: We need to ease the restrictions faced by Chinese companies venturing abroad)," China Daily, 11 September 2013, http://www.chinadaily.com.cn/micro-reading/politics/2013-09-11/content_10082173.html.

49“"Malaysia eyes US\$25 billion investments from China in next five years," The Sun Daily, 6 October 2013.

50 “Chinese FDI in Malaysia: A blessing, curse or opportunity?” Malaysian Reserve, 25 April 2018. 
Gateway ports project. Chinese companies have also signed a memorandum of understanding (MoU) with Malaysian firms to carry out the second phase of the ECRL from Gombak to Port Klang, as well as connect a multi-products gas and petroleum pipeline commencing from Malacca to a refinery under construction in Pengerang, Johor. ${ }^{51}$

Among some of the collaborative investment projects for Malaysia-China that have become icons for both countries' are the Sultan Abdul Halim Muadzam Shah Bridge in Penang, which was an important achievement in bilateral relations. The idea to build the bridge was conceptualized by Dr. Mahathir in 1995, followed by Abdullah's proposal to build the bridge at the south part of Penang to stimulate economic growth in the northern Peninsula states of Malaysia, specifically the Northern Corridor Economic Region (NCER). Besides providing access and communication to the Penang International Airport, this bridge is also seen as a national icon. ${ }^{52}$ Work to construct the bridge commenced in early January 2008 and it was fully completed by February 2014 whereby the opening ceremony was officiated by Najib on 1 March 2014. Construction costs totaled at RM4.5 billion, with a large portion of the loan originating from the Chinese government. The developer in charge of the project was China Harbour Engineering Co. Ltd (CHEC) and the Malaysian counterpart was United Engineers Malaysia Berhad (UEM Group) ${ }^{53}$

Besides that, the existence of the Malaysia-China Kuantan Industrial Park (MCKIP) and Malaysia-China Qinzhou Industrial Park (QIP) equally highlighted an apex a strong symbols of trade between both countries. During Xi Jinping's official visit to Kuala Lumpur, during the Malaysia-China Economic Summit on 4 October 2013, the premier gave justifications for both projects as:

...to build the Qinzhou Industrial Park in China and the Kuantan Industrial Park in Malaysia into collaborative investment projects between both countries, and to encourage industrial development. ${ }^{54}$

The MCKIP, which is 606 hectares wide and located at Gebeng, Kuantan had its opening launched by Najib on 1 May 2013, while the QIP started operations on 1 April 2012. The development of both industrial parks managed to attract many investors and create job opportunities. According to Najib, MCKIP will be developed jointly by Malaysia and China based on the principle of spearheaded by the government, driven by the private sector which targets investment in high technology industries from Malaysian, Chinese and foreign investors from the ASEAN region as well as the world.

The QIP Park was developed in Kunming, the biggest city in the Yunnan region and is in a strategic area as the Qinzhou Free Port with a width of 86 kilometers coastline acting as the easiest access for Southwest China to ASEAN countries. The QIP Park which was built on an area as wide as 55 kilometers per square foot, is expected to play an important role as the entry point for Malaysian products and companies to penetrate the vast Chinese domestic market. Both projects were led by a consortium of companies from Malaysia headed by

\footnotetext{
51 'Investments from China won't necessarily benefit Malaysia', 6 July 2017.

https://www.freemalaysiatoday.com/category/nation/2017/07/06/investments-from-china-wont-necessarilybenefit-malaysia/. Accessed on 3 October 2018.

52 Najib Razak's speech in officiating the Sultan Abdul Halim Muadzam Shah Bridge. 5 March 2014. http://www.1malaysia.com.my/blog/jambatan-kedua-pulau-pinang/

53“"Jambatan Kedua Pulau Pinang,” 28 February 2014.

http://malaysianreview.com/42500/gambar-jambatan-kedua-pulau-pinang/

54 Taman Perindustrian Rapatkan Malaysia-China. Utusan Online, November 2012.

http://www.utusan.com.my/utusan/Ekonomi/20121114/ek_02/Taman-perindustrian-rapatkan-Malaysia-China
} 
Rimbunan Hijau Group and SP Setia Bhd Group while China was represented by Guangxi Beibu Gulf International Port Group and Qinzhou Jingu Investment Company. ${ }^{55}$

Besides the above projects, the Iskandar Development Project is worth mentioning as it is a new attraction in the economic growth corridor at the South of the Peninsula. Since 2011, there have been a few Chinese firms that put in capital like the Zhuoda Real Estate Group at the Medina North, Iskandar area with the total investment of RM158 million in September 2011 and the Country Garden Holdings Ltd at Danga Bay, Iskandar with a capital of RM900 million as well as the Guangzhou R\&F Properties with an investment of RM4.5 billion in November 2013. In 2014, FDI to Malaysia mainly originated from Singapore, Japan, the Netherlands, the United States and Norway, which amounted to RM257.7 billion (US $\$ 58$ billion), or 55.1 percent of the total FDI. However, since 2016, FDI from China has increased tremendously. For example, China's Guangzhou R\&F Properties Co Ltd is investing RM4.5 billion to build condominiums in Iskandar, while Country Garden Holdings Co Ltd is investing RM900 million in 45 condominium towers, offering a total of 9,500 units. In the state of Pahang, Guangxi Beibu Gulf International Port Group is spending RM8 billion to expand and deepen the provincial capital's Kuantan port on the Eastern seaboard as well as build the Malaysia-China Kuantan Industrial Park. ${ }^{56}$

Regarding Malaysian investments in China, up to 2012, the accumulated total of Malaysia's FDI to China was RM20.6 billion (US $\$ 6.3$ billion). This total was about $1 / 5$ of the overall total of China's FDI to Malaysia, which was RM4.4 billion from 2000-2012. ${ }^{57} \mathrm{Up}$ to 2009, as many as 57 large Malaysian firms had been registered by MATRADE to operate in China. Among the sectors that Malaysian investors were involved in are banking, finance, petroleum, business services, engineering and machinery, steel, construction, transport, and trade. Besides that, Malaysian small and medium entrepreneurs (SMEs) were also one of the contributors to Malaysia's FDI to China. According to internal sources from Anbound Research Center Malaysia, these SMEs not only contribute to Malaysia's FDI to China, but were also the majority of investors to China. ${ }^{58}$

Comparatively, Malaysia's investment in China is not as encouraging as China's investment in Malaysia. China's rather complex business culture required persistent effort from Malaysian investors to find business partners to penetrate the growing Chinese market. For years, Malaysia has been one of the few ASEAN countries that invested more in China than China invested in it. Flows of Malaysian FDI into China grew from US\$251 million in 2003 to over US $\$ 400$ million in 2009, at which point the trend reversed. By 2013, flows of Malaysian FDI into China stood at US\$280 million, while flows of Chinese FDI into Malaysia reached a new high of US\$616 million, and by 2017, the figure reached to almost US\$4 billion. ${ }^{59}$

\section{Socio-cultural Cooperation}

Malaysia-China socio-cultural cooperation became gradually enhanced in two sectors, in the education and tourism sectors. Up to 2014, there were about 14,000 Chinese students that

\footnotetext{
${ }^{55}$ Najib Cadang Taman Perindustrian Sekutu di Malaysia. Bernama, 1 April 2012. http://www.1malaysia.com.my/zh/news_archive/najib-cadang-taman-perindustrian-sekutu-di-malaysia/ ${ }^{56}$ South China Morning Post, 12 January 2016.

${ }^{57}$ Sama as above; and Najib Razak, Speech Celebrating The Business Forum Organized by the Malaysian government in Beijing, 4 June 2009, http://www.pmo.gov.my/?menu=speech\&page=1676\&news_id=127\&speech_cat=2.

58 Internal sources from Anbound Research Center (Malaysia).

59 “Chinese FDI in Malaysia: A blessing, curse or opportunity?” Malaysian Reserve, 25 April 2018.
} 
were studying in Malaysia ${ }^{60}$ and the Chinese government also encouraged students from Malaysia to further their studies in China. It cannot be denied that the higher education sector is crucial in building human capital as this field was the basis for long term development for both countries. During Chinese Prime Minister, Wen Jiabao's visit to Malaysia in 2011, he stated that cooperation in the education sector would be further enhanced and tightened when both parties learnt other's language respectively. ${ }^{61} \mathrm{Up}$ to today, there are six universities in China that offer Malay Language Studies, which includes the Chinese Communication University, Peking University, Guandong Foreign Studies University, Guangxi National University, Yunnan National University and Beijing Foreign Language Studies University. ${ }^{62}$ As early as 1962, several measures had been implemented to ensure Malay Language and Chinese Language studies continue to grow and eventually bring about benefits for MalaysiaChina bilateral relations.

The establishment of Xiamen University's branch campus in Malaysia is testimony to the fact that both countries were serious in increasing educational collaborations. The Malaysian government gave permission for the construction of this university campus in Salak Tinggi and it became fully operational in September 2015. The establishment of this campus was historic as it was the first time the Chinese government allowed one of its universities to set up a branch campus overseas. Meanwhile, at University of Malaya, a record number of 171 first degree students from China took up various academic programs up to 30 April 2014, while the total of Masters and PhD students was a lot more. The University of Malaya also allowed for the establishment of the Kong $\mathrm{Zi}$ Institute which was officiated on 1 November 2009 by the Chinese Prime Minister, Li Keqiang. The institute is a collaboration between the University of Malaya and the Beijing Foreign Studies University (BFSU). The aim of the institute is to enhance the understanding of Chinese language and culture in Malaysia as well as encourage the expansion of comprehending a variety of foreign cultures. ${ }^{63}$ The advent of Chinese educational institutions in Malaysia is not surprising given that the country is an education hub in Southeast Asian. In 2016, the United Nations Educational, Scientific and Cultural Organization (UNESCO) stated that Malaysia was among the favorite education destinations for international students. Among the reasons cited include quality of education, cost, quality of life and cultural comfort. As of 31 December 2016, there were 172,886 international students in higher education institutions, private and international schools, as well as language centers. In higher education alone, there were 132,710 international students and the majority of them were from China. According to the QS Best Student Cities 2017 survey, Kuala Lumpur was voted as the world's most affordable city for students for the third time in five years. ${ }^{64}$

The tourism sector has also provided a positive impact on Malaysia-China sociocultural relations. In 2017, China was listed as the fourth most popular tourist destination in the world with the arrival of 60.7 million tourists compared to 59.3 million tourists in $2016 .{ }^{65}$ China also emerged as the main country in Asia to receive the most number of tourists since 2010 and this trend is expected to increase due to the eventual expansion of the Muslim

\footnotetext{
${ }^{60}$ Dato' Abdul Majid Ahmad Khan, "Malaysia-China Relations: Reflections on Four Decades of MalaysiaChina Enhanced Friendship and Partnership". Refer http://ppmc.com.my/en/?page_id=94.

61 Kerjasama Akrab Pendidikan Malaysia, China. Utusan Malaysia, 29 April 2011. http://www.umlib.um.edu.my/newscut_details.asp?cutid=3236\#sthash.IMTohoBb.dpbs 21 April 62 Pengajian Melayu Semakin $\begin{gathered}\text { Meluas. Utusan } \\ \text { http://www.utusan.com.my/utusan/info.asp?y=2011\&dt=0421\&pub=Utusan_Malaysia\&sec=Muka_Hadapan\&p }\end{gathered}$ $\mathrm{g}=\mathrm{mh} \_03 . \mathrm{htm}$

${ }^{63}$ Institute Kong $\mathrm{Zi}$, University of Malaya. www.kongzium.edu.my

64 "Turning the world towards Malaysian education," New Straits Times, 7 May 2017.

${ }^{65}$ https://www.e-unwto.org/doi/pdf/10.18111/9789284419876. Browsed on 9 November 2018.
} 
tourism industry. Although Malaysia was once ranked tenth as the most popular tourist destination in 2012 with a record of 25 million tourists, however Thailand has overtaken Malaysia's spot since 2016. Comparatively, the United States as well as European countries like France, Spain, Italy and Germany received more tourists compared to Asian countries. Table 3 shows the total tourists that visit Malaysia from 2008 to 2017. The trend in tourist arrivals to Malaysia demonstrates a slow increase in the last six years. Nonetheless, Malaysia received the most tourists among the ASEAN countries and this contributed RM66.44 billion to the country's income in 2013. ${ }^{66}$ In 2014, the Tourism Ministry's target to attract 28 million tourists to Malaysia hit a snag when about $30 \%$ of Chinese tourists cancelled their holiday plans to Malaysia due to the disappearance of the MH370 aircraft. ${ }^{67}$

Table 3: International Tourist Arrivals to Malaysia, 2008-2017

\begin{tabular}{|c|c|}
\hline Year & Total Tourists (Million) \\
\hline 2008 & 22.0 \\
\hline 2009 & 23.6 \\
\hline 2010 & 24.6 \\
\hline 2011 & 24.7 \\
\hline 2012 & 25.0 \\
\hline 2013 & 25.7 \\
\hline 2014 & 27.4 \\
\hline 2015 & 25.7 \\
\hline 2016 & 26.8 \\
\hline 2017 & 26.0 \\
\hline
\end{tabular}

Source: Tourism Malaysia, 2018

However, Malaysia's tourism industry indicated signs of recovery in 2016 with the latest figures showing more tourists visiting the country after the slowdown in 2015. Tourist arrivals to Malaysia for 2016 registered a hike of $4.0 \%$ compared to the same period in 2015 . The country received 26.8 million tourists compared to 25.7 million tourists in 2015 . The top ten tourist generating markets to Malaysia in 2016 were Singapore (13.3 million), Indonesia (3.1 million), China (2.1 million), Thailand (1.8 million), Brunei (1.4 million), India (0.64 million), South Korea (0.44 million), the Philippines ( 0.42 million), Japan ( 0.41 million) and the United Kingdom (0.40 million) ${ }^{68}$ Table 4 shows the total number of tourist arrivals in Malaysia for a ten-year period which highlighted an almost uniform increase from 2008 to 2011. However, there was a higher rate of increase in 2012 and 2013 which recorded the total of 1.5 million tourists and 1.8 million tourists. One factor which caused the hike in the number of Chinese tourists to Malaysia was the mutual operation code project between China Southern Airlines and Malaysia Airlines since March 2012 that increased the frequency of Beijing-Kuala Lumpur flights to two flights daily. The Cathay Pacific company also added on seven flights weekly between Hong Kong-Malaysia and three flights weekly between Hong Kong-Penang which further facilitated the convenience of travel for tourists from China to Malaysia. Not to be left behind was Air Asia that offered three flights weekly for the Hong

\footnotetext{
66 “Malaysia’s Tourism Industry Exceeds Expectations in 2013," Astro Awani, 28 February 2014.

67 "MH370 Tragedy Affects Chinese Tourist Arrivals, 30 Per Cent of Trips Cancelled," Bernama, 17 April 2014.

${ }^{68}$ Malaysia’s 2016 Tourist Arrivals Grow 4.0\%, Putajaya, 7 March 2017,

https://www.tourism.gov.my/media/view/malaysia-s-2016-tourist-arrivals-grow-4-0
} 
Kong-Kota Kinabalu journey. ${ }^{69}$ Meanwhile, AirAsia X offered six direct flights from Shanghai to Kuala Lumpur and seven direct flights from Hangzhou to Kota Kinabalu. ${ }^{70}$

Table 4: Total Number of Chinese Tourists to Malaysia from 2008 - August 2018

\begin{tabular}{|c|c|}
\hline Year & Total Tourists (Million) \\
\hline 2008 & 0.9 \\
\hline 2009 & 1.0 \\
\hline 2010 & 1.1 \\
\hline 2011 & 1.2 \\
\hline 2012 & 1.5 \\
\hline 2013 & 1.8 \\
\hline 2014 & 1.6 \\
\hline 2015 & 1.7 \\
\hline 2016 & 2.1 \\
\hline 2017 & 2.3 \\
\hline August 2018 & 2.1 \\
\hline
\end{tabular}

Source: Tourism Malaysia, 2018

Starting from 2016, for the first time Malaysia received a total of more than 2.1 million Chinese tourists. Moreover, in 2017, this number jumped to 2.3 million tourists. It was even more encouraging when up to August 2018, as many as 2.1 million tourists had already visited Malaysia and their main destinations were not merely the big cities but also the islands and beaches of Sabah and Peninsula Malaysia. Once can argue that the role played by the TDC to promote Malaysia as the main tourist destination in Southeast Asia's tropical region has was successful in attracting Chinese tourists.

The MM2H Program (Malaysia My Second Home) which was launched by the Malaysian government in 2002 to enable foreign citizens who have fulfilled certain requirements to settle in Malaysia long term also attracted a number of Chinese to Malaysia. This program allows applicants to bring along their partner, parents of more than 60 years of age and children below 21 years of age. Applications are open to citizens recognized by Malaysia without regardless of race, religion or gender. Several aspects encouraged the applicants of this program, such as Malaysia's stable economy, sophisticated and efficient transportation system. Applicants feel that public transportation such as buses, taxis, light rail transit, trains and airplanes offer comfort at affordable prices. ${ }^{71}$ From 2013 up to August 2017, the number of Chinese citizens that joined the MM2H was the highest compared to other nationalities. The number of Japanese citizens that previously occupied the first rank began dropping since 2013 and their place was replaced by Chinese citizens. Table 5 shows the top ten participating countries in the MM2H program from 2002 until August 2017.

\footnotetext{
69 Tourist Arrivals in Malaysia Continue to Increase, 4 September 2012. Travel Daily News. http://www.traveldailynews.asia/news/article/50330/tourist-arrivals-in-malaysia-continue

70 Malaysia's Tourism Industry Exceeds Expectations in 2013, 28 February 2013. http://english.astroawani.com/news/show/malaysias-tourism-industry-exceeds-expectations-in-2013-30982

71 Portal Pusat Maklumat Rakyat (PMR). http://pmr.penerangan.gov.my/index.php/sosial/5549-programmalaysia-rumah-kedua-ku-.html
} 
Table 5: Top Ten Participating Countries in Malaysia My Second Home (MM2H) Program, 2002-August 2017

\begin{tabular}{|c|c|c|c|c|c|c|c|c|c|c|c|c|}
\hline \multirow[b]{3}{*}{ Year } & & \multicolumn{11}{|c|}{ Country of Nationality } \\
\hline & 1 & 2 & 3 & 4 & 5 & 6 & 7 & 8 & 9 & 10 & 11 & \\
\hline & שี & 言 & 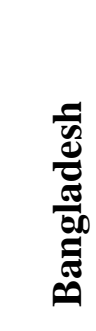 & 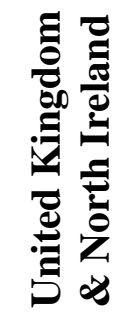 & $\stackrel{1}{0}$ & 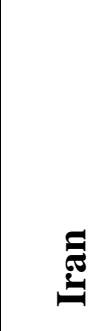 & 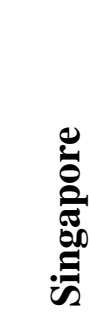 & 预 & 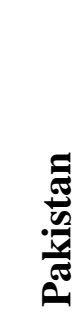 & 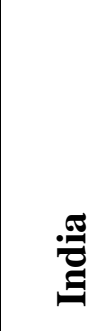 & $\frac{\mathscr{2}}{0}$ & Total \\
\hline 2002 & 241 & 49 & - & 108 & 5 & - & 96 & 38 & 9 & 45 & 227 & 818 \\
\hline 2003 & 521 & 99 & 32 & 159 & 12 & 2 & 143 & 95 & 55 & 123 & 404 & 1,654 \\
\hline 2004 & 468 & 42 & 204 & 210 & 66 & 8 & 91 & 140 & 82 & 118 & 488 & 1,917 \\
\hline 2005 & 502 & 87 & 852 & 199 & 60 & 7 & 62 & 186 & 104 & 80 & 476 & 2,615 \\
\hline 2006 & 242 & 157 & 341 & 209 & 65 & 9 & 94 & 63 & 36 & 51 & 462 & 1,729 \\
\hline 2007 & 90 & 198 & 149 & 240 & 152 & 59 & 58 & 31 & 31 & 46 & 449 & 1,503 \\
\hline 2008 & 120 & 210 & 68 & 208 & 86 & 227 & 48 & 16 & 65 & 32 & 432 & 1,512 \\
\hline 2009 & 114 & 169 & 86 & 162 & 54 & 212 & 61 & 36 & 103 & 35 & 546 & 1,578 \\
\hline 2010 & 154 & 195 & 74 & 141 & 49 & 227 & 73 & 49 & 77 & 51 & 409 & 1,499 \\
\hline 2011 & 405 & 423 & 276 & 153 & 64 & 286 & 78 & 70 & 136 & 50 & 446 & 2,387 \\
\hline 2012 & 731 & 816 & 388 & 139 & 83 & 201 & 83 & 85 & 100 & 56 & 545 & 3,227 \\
\hline 2013 & $\begin{array}{l}1,3 \\
37\end{array}$ & 739 & 285 & 148 & 101 & 51 & 145 & 151 & 58 & 41 & 619 & 3,675 \\
\hline 2014 & $\begin{array}{l}1,3 \\
07\end{array}$ & 428 & 250 & 117 & 137 & 17 & 94 & 83 & 51 & 42 & 548 & 3,074 \\
\hline 2015 & 719 & 300 & 205 & 83 & 120 & 19 & 67 & 71 & 31 & 46 & 550 & 2,211 \\
\hline 2016 & $\begin{array}{l}1,5 \\
12\end{array}$ & 281 & 283 & 110 & 184 & 8 & 93 & 77 & 29 & 68 & 702 & 3,347 \\
\hline $\begin{array}{l}\text { Augu } \\
\text { st } \\
2017\end{array}$ & $\begin{array}{l}1,4 \\
39\end{array}$ & 179 & 253 & 113 & 278 & 18 & 60 & 80 & 25 & 53 & 586 & 3,084 \\
\hline Total & $\begin{array}{l}9,9 \\
02\end{array}$ & $\begin{array}{l}4,3 \\
72\end{array}$ & $\begin{array}{l}3,74 \\
6\end{array}$ & $\begin{array}{l}2,49 \\
9\end{array}$ & $\begin{array}{l}1,51 \\
4\end{array}$ & $\begin{array}{l}1,35 \\
1\end{array}$ & $\begin{array}{l}1,34 \\
6\end{array}$ & $\begin{array}{l}1,2 \\
71\end{array}$ & 992 & 937 & $\begin{array}{l}7,89 \\
1\end{array}$ & $\begin{array}{l}35,82 \\
1\end{array}$ \\
\hline $\begin{array}{l}\text { Shar } \\
\text { e }(\%)\end{array}$ & $\begin{array}{l}27 . \\
6\end{array}$ & $\begin{array}{l}12 . \\
2\end{array}$ & 10.5 & 7.0 & 4.2 & 3.8 & 3.8 & 3.5 & 2.8 & 2.6 & 22.0 & 100 \\
\hline
\end{tabular}

Source: Malaysia My Second Home (MM2H) Portal ${ }^{72}$

\section{Malaysia-China Ties under Dr. Mahathir's Administration}

It is indeed Dr. Mahathir who first set the tone for Malaysia's China policy. ${ }^{73}$ About 33 years ago in November 1985 on his first official visit to China, accompanied by a great

\footnotetext{
72 http://www.mm2h.gov.my/index.php/en/home/programme/statistics

${ }^{73}$ Dennis Ignatius, “33 years after Dr Mahathir's first visit to China,” FMT News, 3 September 2018.
} 
number of Malaysian entrepreneurs and investors, he predicted the enormous potential and importance of China and wanted to position Malaysia as Beijing's strategic partner. Gradually, Kuala Lumpur-Beijing relations developed with the elimination of many past barriers. Instead, ideology was taken over by giving emphasis to trade and investment relations. It was Dr. Mahathir who changed the narrative from a Malaysian policy of suspicion and distrust to viewing China as an opportunity rather than a threat.

On 9 May 2018, Malaysia witnessed a change of government when Pakatan Harapan won the elections. In his congratulatory message, when the Prime Minister was sworn in on 10 May 2018, Chinese Premier Li Keqiang referred to Mahathir as a Malaysian and regional 'senior politician' who had made proactive and important contributions to the development of Malaysia and ASEAN as well as China-Malaysia and East Asian cooperation. Li said that his country 'highly valued' China-Malaysia relations and that he was willing to work together with Dr. Mahathir to further the stable development of the strategic partnership between the two countries. ${ }^{74}$ Despite the optimism, soon after, Dr. Mahathir announced that major infrastructure projects funded by Chinese state companies could not be implemented because the nation is in a financial crunch. Moreover he hinted that the projects were obviously lopsided favoring the Chinese companies more than their Malaysian partners. In announcing his decision, Dr. Mahathir made it very clear that the lopsidedness was due to the previous Malaysian government and not the Chinese counterpart. ${ }^{75}$ Being pragmactic, Dr. Mahathir stressed that China is an important trading partner for Malaysia and Kuala Lumpur will deepen its bilateral relations with Beijing. It is clear for Dr. Mahathir that he has no intention to sideline China in Malaysia's foreign policy formulation. At the time of writing, Malaysia had already suspended the East Coast Railway Line (estimated to cost RM55 billion or more) and the Multi-Product Pipeline as well as the Trans-Sabah Gas Pipeline (estimated at RM9.4 billion) on grounds that they are too costly and would put Malaysia in further debt.

Dr. Mahathir's five-day visit to China in August 2018 was to seek Beijing's understanding in canceling the ECRL and other projects that the new government concluded made absolutely no economic sense. By travelling to Beijing for personal discussions with the Chinese leadership, it provided an opportunity to reassure the Chinese that despite the cancellation of projects, Malaysia remained deeply committed to developing closer and mutually beneficial relations with China. Following bilateral discussions, President Xi appears to have accepted Mahathir's decision to postpone the projects because of Malaysia's current fiscal position. A Chinese foreign ministry statement subsequently noted that "however the situation may evolve, the two countries will always hold friendly policies towards each other". It added that the cancellation of projects "will not hinder future bilateral trade and economic relations". ${ }^{76}$ Before his departure for Kuala Lumpur, Dr. Mahathir further stated, "...the projects will not go on. At the moment, the priority is reducing our debt ... it will be deferred until such time when we can afford, then maybe we will reduce the cost.",77 Looks like Dr. Mahathir is very much interested in learning more about China's recent success in economic development, and would like to direct closer cooperation to particular

\footnotetext{
${ }^{74}$ Lye Liang Fook, Mahathir's China Visit and Malaysia-China Relations: The View from China, ISEAS Perspective, No. 53, 7 September 2018, p. 4.

${ }^{75}$ Chandra Muzaffar, A New Imperial Power? International Movement for a Just World (JUST), 22 October 2018.

${ }^{76}$ Dennis Ignatius, Mahathir's China visit a success, Free Malaysia Today, 23 August 2018.

77 “Chinese 'projects will not go on': Mahathir blasts Najib's 'stupidity', ” South China Morning Post, 22 August 2018.
} 
fields. Therefore, it is expected that Dr. Mahathir will continue to court China, even while keeping the long-standing balancing strategy in place. ${ }^{78}$

From the aspect of investments, China's FDI in the manufacturing sector is continuing in Malaysia. Table 6 shows the number of manufacturing sector projects based on China's FDI in Malaysia beginning of January up to June 2018. Among the five main FDI countries in Malaysia, China is the largest investor with a total of 17 projects and investment value of RM6.6 billion. This total is the highest number among Northeast Asian countries and matched the total investment from South Korea and Japan. In another example, China's interest in the development project in Labuan, for instance has seen the investor waiting for approval from the Federal Territory Ministry.

Table 6: Number of Manufacturing Projects through China FD
Malaysia,
\begin{tabular}{|l|l|l|}
\hline Country & Number & $\begin{array}{l}\text { Foreign Investment } \\
(\text { RM Million) }\end{array}$ \\
\hline \hline China & 17 & $6,557.6$ \\
\hline $\begin{array}{l}\text { Republic of } \\
\text { Korea }\end{array}$ & 5 & $\mathbf{2 , 4 1 5 . 3}$ \\
\hline Japan & 25 & $1,558.7$ \\
\hline Singapore & 29 & $\mathbf{8 4 1 . 5}$ \\
\hline France & 4 & 591.1 \\
\hline
\end{tabular}

Source: MIDA Malaysia

Besides manufacturing, if successful, a Chinese investor is expected to spend a whopping RM8 billion to develop an international island resort and marina destination off Kuraman Island, while creating 10,000 jobs for the oil and gas heavily-dependent duty-freeisland. Once the approval come through, construction of the mammoth 147-hectare multihotel, residential and commercial project is slated to begin early 2019. The project would consist of 16 three- to six-star resort hotels, a tourism town enclave, condominiums and apartments, international marinas, a wellness center, a water world theme park, a sea water lagoon and a signature seafood restaurant. There will be three more man-made islands, namely Kuraman 2, 3 and 4 to be built in stages around the existing Kuraman Island which is expected to be fully completed by 2029. The Labuan Corporation chairman, Amir Hussien said the ten-year master plan, slated from 2019 onwards is expected to provide multiplier effects of RM1 billion for Labuan and at least 800,000 tourist arrivals per year to the island. ${ }^{79}$

\section{Conclusion}

The Malaysian top leadeship has been pivotal in promoting Malaysia-China relations. Specifically, Abdul Razak's significant contribution that pioneered the path towards Malaysia-China diplomatic relations 40 years ago was extremely crucial in iniating bilateral relations. Abdul Razak's contribution is equally appreciated by the Chinese side. The statement below indicated how the Chinese look up to Tun Razak's family,

\footnotetext{
${ }^{78}$ Li Xirul, Malaysia’s China Policy: The More Things Change ...," The Diplomat, 12 September 2018.

79 "China firm to build RM8b resort off Labuan's Kuraman Island,” New Straits Times, 1 November 2018.
} 
China looked up to what Tun Razak had achieved to create diplomatic relations with China, when the country had been isolated by the world at that time. That is why, every Chinese ambassador who is sent to be on duty in Malaysia, will invite Tun Rahah (Tun Abdul Razak's widow) as a special guest. $^{80}$

The injection of Dr. Mahathir's idea into focusing on economic cooperation and investments beginning 199s further strengthened trade relations replacing the weak Kuala Lumpur-Beijing relations of 1974-1989. Najib's stance was similar to Dr. Mahathir's in which he too he stressed on economic cooperation with China for mutual benefits. Overall, Malaysia, which is also claiming a part of Spratly Islands in the region of 200 nautical miles of its Exclusive Economic Zone (EEZ), is not any less worried about the rise of China. However, Malaysian diplomacy has always been to engage rather than creating conflicts. In other words peace is being maintained by strengthening economic and investment relations with China as a mechanism in invoking a progressive Kuala Lumpur-Beijing bilateral relationship.

\section{References}

Ahmad Kamil Jaafar, Growing Up with the Nation, Singapore: Marshall Cavendish, 2013. Bernama News, 27 August 1996.

Bernama News, 31 May 2013. Keynote speech by Tan Sri Dato' Michael Chen Wing Sum at the Photo Exhibition Celebrating the 40th Anniversary of the Establishment of MalaysiaChina Diplomatic Relations at University of Malaya on 21 April 2014. Chandra Muzaffar, A New Imperial Power? International Movement for a Just World (JUST), 22 October 2018.

"China firm to build RM8b resort off Labuan's Kuraman Island," New Straits Times, 1 November 2018.

"China to negotiate upgraded FTA with ASEAN," Xinhua, 26 October 2013, http://news.xinhuanet.com/english/china/2013-10/26/c_125601659.htm.

"China to Promote Maritime Connectivity with ASEAN, Says Vice FM," Xinhua, 5 August 2012, http://www.gov.cn/misc/2012-08/05/content_2198775.htm.

"China Visits Under Study Says Khir," The Star, 13 January 1972; "China Visits Rules Will be Reviewed Dewan Told," The Star, 5 February 1970.

China Daily. http://www.chinadaily.com.cn/china/2009malaysia/2009-

06/01/content_7959800.htm. Accessed on 23 June 2018.

China will import more palm oil products from Malaysia: Chinese Ambassador to Malaysia," New Straits Times, 2 February 2018.

"China's 2012 GDP growth rate at 7.5\%," Xinhua, 5 March 2012, http://news.xinhuanet.com/english/china/2012-03/05/c_131446465.htm

“Chinese 'projects will not go on': Mahathir blasts Najib's 'stupidity'," South China Morning Post, 22 August 2018.

"Chinese FDI in Malaysia: A blessing, curse or opportunity?" Malaysian Reserve, 25 April 2018.

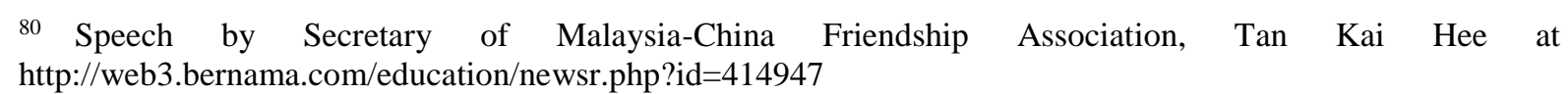


Dato' Abdul Majid Ahmad Khan, "Malaysia-China Relations: Reflections on Four Decades of Malaysia-China Enhanced Friendship and Partnership". Retrieved from http://ppmc.com.my/en/?page_id=94.

“Gemas-JB double tracking still in designing phase," New Straits Times, 27 December 2011. Hirschman, Charles, "The Making of Race in Colonial Malaya: Political Economy and Racial Ideology," Sociology Forum, Vol. 1, Issue 2, Spring 1986.

Griffin, Nicholas, Ping Pong Diplomacy: The Secret History Behind the Game That Changed the World, New York: Simon \& Schuster, 2014.

Guotu, Zhuang, and Wang Wangbo, "Migration and Trade: The Role of Overseas Chinese in Economic Relations between China and Southeast Asia," International Journal of China

Studies, Vol. 1, No. 1, January 2010.

Hirschman, Charles, "The Making of Race in Colonial Malaya: Political, Economy and Racial Ideology," Sociology Forum, Vol. 1, Issue 2, Spring 1986.

http://eprints.usm.my/15538/1/Sejarah_Panjang_Hubungan_Malaysia_-_China.pdf

http://malay.cri.cn/781/2009/05/30/181s99084.htm

http://malay.cri.cn/901/2010/03/30/123s110068.htm,

http://www.utusan.com.my/utusan/info.asp? y=2009\&dt=0607\&sec=rencana\&pg=re_09.htm

http://malaysianreview.com/42500/gambar-jambatan-kedua-pulau-pinang/

http://www.kppk.gov.my/index.php/ms/2012-10-31-06-45-41/mpic-in-the-news/news-year-

2013/2067-industri-sawit-douglas-optimistik-pelarasan-duti-eksport-tidak-jejas-eksport-msmke-china.html

http://www.kppk.gov.my/index.php/ms/2012-10-31-06-45-41/mpic-in-the-news/news-year2013/2067-industri-sawit-douglas-optimistik-pelarasan-duti-eksport-tidak-jejas-eksport-msmke-china.html

http://www.mm2h.gov.my/index.php/en/home/programme/statistics

http://www.umno-online.my/?p=62832

http://www.usahawan.com/umum/industri-sawit-di-malaysia.html

https://www.e-unwto.org/doi/pdf/10.18111/9789284419876.

Ignatius, Dennis, “33 years after Dr Mahathir's first visit to China," FMT News, 3 September 2018.

Ignatius, Dennis, Mahathir's China visit a success, Free Malaysia Today, 23 August 2018.

"Investments from China won't necessarily benefit Malaysia," Free Malaysia Today, 6 July

2017. https://www.freemalaysiatoday.com/category/nation/2017/07/06/investments-fromchina-wont-necessarily-benefit-malaysia/.

Isaacson, Walter, Kissinger, New York: Simon \& Schuster, 1992.

Katayama, Kazuyuki, China's Rise and Japan's Malaysian Policy, Kuala Lumpur: UM

Press, 2013.

"Kerjasama Akrab Pendidikan Malaysia, China." Utusan Malaysia, 29 April 2011. http://www.umlib.um.edu.my/newscut_details.asp?cutid=3236\#sthash.IMTohoBb.dpbs

Keynote Speech by Tan Sri Dato' Michael Chen Wing Sum at the Photo Exhibition

Celebrating the 40th Anniversary of the Establishment of Malaysia-China Diplomatic

Relations at University of Malaya on 21 April 2014.

Kong, Yuanzhi, Cheng Ho Muslim Tionghoa: Misteri Perjalanan Muhibah di Nusantara, Jakarta: Yayasan Pustaka Obor Indonesia, 2011.

"Li Keqiang: Yao jinyibu fangkuan zhongguo qiye "zouchuqu" de tiaojian (Li Keqiang: We need to ease the restrictions faced by Chinese companies venturing abroad)," China Daily, 11 September 2013, http://www.chinadaily.com.cn/micro-reading/politics/2013-0911/content_10082173.html. 
Li Xirul, Malaysia's China Policy: The More Things Change ...," The Diplomat, 12 September 2018.

Lukman Thaib, "Kedinamikan Hubungan ASEAN-China: Rujukan Khas ke atas Malaysia," in Obaidellah Mohamad (ed.), China: Isu dan Hubungan Luar, Kuala Lumpur: Institute of Chinese Studies, University of Malaya, 2004, p. 220.

Lye Liang Fook, "Mahathir's China Visit and Malaysia-China Relations: The View from China," ISEAS Perspective, No. 53, 7 September 2018.

"Malaysia eyes US\$25 billion investments from China in next five years," The Sun Daily, 6 October 2013.

"Malaysia's Tourism Industry Exceeds Expectations in 2013," Astro Awani, 28 February 2014.

"Malaysia-China target US\$160 bln in bilateral trade by 2017," New Straits Times, 4 October 2013, http://www.nst.com.my/mobile/latest/malaysia-china-target-us-160-bln-in-bilateraltrade-by-2017-1.368942

"Malaysian PM Echoes Beijing's Call for Joint Development in South China Sea," South China Morning Post, 5 June 2013, www.scmp.com/new s/asia/article/1253564/malaysianpm-echoes-beijings-call-joint-development-south-china-sea.

"Malaysia’s 2016 Tourist Arrivals Grow 4.0\%, Putrajaya," 7 March 2017, https://www.tourism.gov.my/media/view/malaysia-s-2016-tourist-arrivals-grow-4-0 "Malaysia's Tourism Industry Exceeds Expectations in 2013," Astroawani, 28 February 2013. http://english.astroawani.com/news/show/malaysias-tourism-industry-exceedsexpectations-in-2013-30982

Malaysian Prime Minister's speech, Dato Sri Mohd. Najib bin Hj. Tun Razak, "The Opening Session of the National Colloquium on Malaysia's Chairmanship of ASEAN 2015," Malaysian Prime Minister's Department, 8 April 2014, http://www.pmo.gov.my/?menu=speech\&page=1676\&news_id=700\&speech_cat=2. Md. Nasrudin bin Md. Akhir, "Jepun dan Krisis Kewangan Asia Tenggara," (Japan and the Southeast Asian Financial Crisis) Pemikir, July-September 2000.

Md. Nasrudin Md. Akhir, "Five Decades of Malaysia-Japan Relations," in Md. Nasrudin Md. Akhir \& Rohayati Paidi (eds.), Japan and the Asia-Pacific, Kuala Lumpur: Department of East Asian Studies, 2009.

Md. Nasrudin Md. Akhir, "Issues in Malaysia-Japan Relations Under the Abdullah Ahmad Badawi's Administration," in Md. Nasrudin Md. Akhir \& Asmadi Hassan (eds.), Japan and East Asian Regionalism, Kuala Lumpur: Department of East Asian Studies, Kuala Lumpur, 2008.

"MH370 Tragedy Affects Chinese Tourist Arrivals, 30 Per Cent of Trips Cancelled," Bernama News, 17 April 2014.

"Najib Cadang Taman Perindustrian Sekutu di Malaysia." Bernama News, 1 April 2012. http://www.1malaysia.com.my/zh/news_archive/najib-cadang-taman-perindustrian-sekutu-dimalaysia/.

"Najib Razak, Speech Celebrating The Business Forum Organized by the Malaysian government in Beijing," Prime Minister's Office, 4 June 2009, http://www.pmo.gov.my/?menu=speech\&page=1676\&news_id=127\&speech_cat=2. "Perkara Penting dalam Sejarah Hubungan RRC-Malaysia." March, 2010. http://malay.cri.cn/901/2010/03/30/123s110068.htm “Pengajian Melayu Semakin Meluas." Utusan Online, 21 April 2011. http://www.utusan.com.my/utusan/info.asp?y=2011\&dt=0421\&pub=Utusan_Malaysia\&sec= Muka_Hadapan\&pg=mh_03.htm 
"PM Najib arrives in China for official visit," New Straits Times, 31 October 2016; Bernama News, 2 April 2017; "Najib in Beijing for 6-day official visit to China," Malaysian Reserve, 2 April 2017.

"Premier Li Outlined Five Proposals for the Strengthening of ASEAN-China Ties

(Translation from Chinese)," Xinhuanet, 3 September 2013,

http://news.xinhuanet.com/world/2013-09/03/c_117214202.htm.

"Portal Pusat Maklumat Rakyat (PMR)."

http://pmr.penerangan.gov.my/index.php/sosial/5549-program-malaysia-rumah-kedua-ku.html

$\mathrm{Pu}$, Bao, Chiang Renee \& Ignatius, Adi (eds.), Prisoner of the State: The Secret Journal of Zhao Ziyang, London: Simon \& Schuster, 2009.

"Room to grow palm oil exports to China - Kok," New Straits Times, 23 October 2018.

"Secretariat to be formed between Barisan and China's youth wings, The Star, 12 October 2009,http://www.thestar.com.my/story.aspx/?file=\%2f2009\%2f10\%2f12\%2fnation $\% 2 \mathrm{f} 20091$ $012160821 \& \sec =$ nation.

Shee, Poon Kim, "The Political Economy of Mahathir's China Policy: Economic Cooperation, Political and Strategic Ambivalence," Ritsumeikan Annual Review of International Studies, Vol. 3, 2004.

Speech by Secretary of Malaysia-China Friendship Association, Tan Kai Hee at http://web3.bernama.com/education/newsr.php?id=414947

"Taman Perindustrian Rapatkan Malaysia-China." Utusan Online, November 2012. http://www.utusan.com.my/utusan/Ekonomi/20121114/ek_02/Taman-perindustrian-rapatkanMalaysia-China.

Tregonning K. G., (ed.), Malaysian Historical Sources, Singapore: University of Singapore, 1962.

Toh, Han Shih, "Chinese railway builders hit by Malaysian politics," South China Morning Post, 16 January 2012.

"Tourist Arrivals in Malaysia Continue to Increase". Travel Daily News, 4 September 2012. http://www.traveldailynews.asia/news/article/50330/tourist-arrivals-in-malaysia-continue “Tun Razak Gives 'OK' to China Visit,” The Star, 28 September 1972.

"Turning the world towards Malaysian education," New Straits Times, 7 May 2017.

Xia Ming, "Sino-Malaysian Trade Ties and Its Prospects," Economic Quarterly, April 1990. Zhuang Guotu and Wang Wangbo, "Migration and Trade: The Role of Overseas Chinese in Economic Relations between China and Southeast Asia," International Journal of China Studies, Vol. 1, No. 1, January 2010. 